\title{
Multivesssel Umblical Cord: Case Report
}

\author{
Paramanantham P* and Srujana Swarna \\ Department of paediatrics, SRM medical college hospital and research centre, India
}

Submission: December 12, 2017; Published: January 09, 2018

*Corresponding author: Paramanantham P, NICU, Department of paediatrics, SRM medical college hospital and research centre, Katankulathur, India, Email: paramanandham59@yahoo.com

\section{Introduction}

The umbilical cord normally contains three vessels-two umbilical arteries and one umbilical vein (UV). Abnormalities leading to multiple vessels in the cord are rare with majority of the reported cases in literature highlighting four vessels due to a persistent right UV [1-3]. There are only occasional reports mentioning the presence of live vessels in the cord [3]. Out of the 432 placentas examined in our laboratory over a period of 2 years (2009-2011). 4 (0.93\%) showed the presence of more than three vessels on cross section of the umbilical cord. We found three cases with five vessels in the ord and one case with four vessels. In all the four cases, the diagnosis of multiple vessels in the cord was made postnatally on gross examination, and was confirmed by histopathologic examination. One of the 4 cases in the present study showed the presence of five vessels running along the central portion of hte cord, while the maternal and fetal ends showed only three vessels: branching of the vessels could be a possible explanation for this finding.

The umbilical cord is an important vascular appendage which plays a key role in fetal well- being and development. the prenatal as well as postnatal examination of the placenta has contributed significantly to the current knowledge of umbilical cord anomalies and their impact on fetal outcome. Examiination of the cord for the number of vessels is a standard part of routine prenatal ultrasonography (USG). Current guidlines emphasize on the utility of gross examination of the placenta for determining the number of vessels [4]. Thus a careful gross examination and proper sectioning of umbilical cord is extremely important.

\section{Case}

38 year old second gravidia mother who is gestational diabetic delivered a female baby with weight of $3.1 \mathrm{~kg}$ in SRM medical college and hospital in july 2016. The baby cared well at birth. Apgarscope one minute 8 by 10 and 5 minute 9 by 10 . The cut end of the umbilicus of the baby showed one vein and 6 arteries the baby was feeding well cry color and activity was good with normal neonatal reflexes and muscle tone. Postnatal ultrasound of the abdomen was normal. Other systems were normal. Antinatal ultrasound/ Doppler for the mother was not done. The baby was kept under observation in NICU and discharged after 3 days of life the baby is being followed, the development and growth of the baby is normal.

\section{Discussion}

Most common cause of four vessels in umbilical cord is persistent right umbilical vein which normally involutes at 6th7 th week of intrauterine life. This condition is often associated with congenital malformations (in around $18 \%$ cases) like duodenal atresia, imperforate anus, bowel malrotation, annular pancreas, artial septal defect and situs inversus [1-3] but no anomaly seen in our case. There are many reports describing the presence of four vessels and their possible mechanisms discussed in detail $[1-3,5]$. However literature regarding significance of five vessels in umbilical cord is sparse. The association of five vessel cord with congential anomalies is not clearly understood due to the scarcity of literature pertaining to this condition. However, five or more vessels in the cord have mostly been described as a part of conjoined twining [5]. Out of the three cases of fivevessel cord encountered by us, only one had an unfavourable clinical outcome in the form of anencephaly. The other two patients delivered twins with no evidence of any congential malformations. None of our cases had conjoined twinning.

To summarise simple tests like USG examination of placenta and color Doppler are valuable for prenatal diagnosis, which can alter the radiologist to look for congenital malformation and twinning. However, a simple gross examination of the cord postnatally for the number of blood vessels provides a valuable clue for a thorough examination of the neonate to look for subtle anomalies. Five vessels in the cord are frequently associated with twinning not necessarily of conjoined type only and do not always herald an adverse perinatal outcome.

Common cause (up to $5 \%$ of the cords) for the fourth vessel is the persistence of small vitelline arteries. These rarely exceed $0.5 \mathrm{~mm}$ in diameter [5]. In velamentous insertion, the cord is not connected to the placental plate and its vessels travel between 
the membranes before attaching eccentrically to the placenta. It happens in $1.1 \%$ in singleton pregnancies and $8.7 \%$ of twins [6].

\section{References}

1. Tadmor SOP, Yagel S (1996) Prenatal diagnosis of persistent right umbilical vein. Ultrasound Obstet Gynecol 8(1): 31-33.

2. Perez-Cosio C, Sheiner E, Abramowicz JS (2008) Four vessel umbilical cord: Not always a dire prognosis. J Ultrasound Med 27(9): 1389-1391.

3. Schimmel MS, Eidelman AI (1998) Supernumerary umbilical vein resulting in a four vessel umbilical cord. Am J Perinatol 15(5): 299-301.

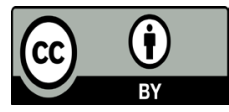

This work is licensed under Creative Commons Attribution 4.0 Licens

DOI: 10.19080/MABB.2018.03.555601
4. Sepulveda W (1999) Time for a more detailed prenatal examination of the umbilical cord? ultrasound obstet Gynecol 13(3):157-160.

5. Meyer WW, Lind J, Moinian M (1969) An accessory fourth vessel of the umbilical cord. A preliminary study. Am J Obset Gynecol 105(7):10631068.

6. Benirschke K, Kaufmann K, Peter (1990) Pathology of the human placenta. In: 5 [Edn.], Springer-Verlag New York, pp. 200-204.

\section{Your next submission with Juniper Publishers will reach you the below assets}

- Quality Editorial service

- Swift Peer Review

- Reprints availability

- E-prints Service

- Manuscript Podcast for convenient understanding

- Global attainment for your research

- Manuscript accessibility in different formats

( Pdf, E-pub, Full Text, Audio)

- Unceasing customer service

Track the below URL for one-step submission https://juniperpublishers.com/online-submission.php 